\title{
FACTOR ENDOWMENTS, MARKETS AND VERTICAL INTEGRATION. THE DEVELOPMENT OF COMMERCIAL WINE PRODUCTION IN ARGENTINA, AUSTRALIA AND CALIFORNIA, C1870-1914*
}

\author{
JAMES SIMPSON \\ Universidad Carlos III de Madrid $^{\mathrm{a}}$
}

\begin{abstract}
Grape quality and the nature of market demand played a major role in determining the organizational structure of the wine industry in the three decades prior to 1914. In contrast to Europe where grape growing and winemaking were specialist activities, in the New World winemaking and selling were often integrated. This encouraged the appearance of large industrial wineries producing wines that could be branded. Differences within the New World itself can be attributable to the nature of demand and, in particular, to whether wine was considered an article of primary consumption (Argentina), or whether it competed with other, more popular alcoholic beverages such as beer and spirits (Australia and California).
\end{abstract}

Keywords: wine factor endowments, firm organization, vertical integration, new settlers, XIX century, grape production, commercial wine production, commodity chains

JEL Code: M21, N51, N56, N57

* Received 9 March 2010. Accepted 26 October 2010. I am particularly grateful to Kym Anderson, Patricia Barrio de Villanueva, Luis Bértola, Luis Coria, Pablo Lacoste, Jim Lapsley, Ana Mateu, Ian McLean, Lizzi Pasteris and Steve Stein for comments and suggestions. Antonio Tena was especially helpful during the preparation of the final version. Two anonymous referees made useful suggestions. The author acknowledges financial support from Spain's Education Ministry (ECO2009-10739 and 2006-08188/ECON).

a Departamento de Historia Económica e Instituciones and Instituto Figuerola de Historia y Ciencias Sociales, Universidad Carlos III de Madrid. james.simpson@uc3m.es 


\section{RESUMEN}

En las tres décadas anteriores a la I Guerra Mundial, la calidad de la uva y la naturaleza de la demanda del mercado jugaron un papel determinante en la estructura organizativa de la industria del vino. En contraste con Europa, donde el cultivo de la uva y la producción del vino fueron actividades especializadas, en el Nuevo Mundo la producción y venta del vino estuvieron integradas verticalmente. Esto favoreció la aparición de grandes industrias vinícolas, que producían vinos de marca. Las diferencias dentro del Nuevo Mundo pueden ser atribuidas a la naturaleza de la demanda, en especial cuando el vino fue considerado un artículo de consumo primario (Argentina), o cuando competía con otras bebidas alcohólicas más populares tales como la cerveza y los alcoholes graduados (Australia y California).

Palabras clave: dotación de factores vinícolas, organización de empresas, integración vertical, Nuevo Mundo siglo XIX, producción de uvas, producción de vino comercial, cambio de mercancías

\section{INTRODUCTION}

Despite the interest of the early European settlers, commercial wine production in the New World only developed in the late $19^{\text {th }}$ century in response to growing urban demand, improved transportation and new winemaking technologies. By 1914, the industry was well established in a number of countries, and contemporaries noted that it had developed very differently from the situation in the Old World. In particular, the new largescale wineries were dependent in a way that was not the case in Europe on specialist grape producers. Wine producers were much more involved in marketing, and wines were often sold under brand names. Important differences also existed among New World producers themselves, especially with respect to the marketing and distribution of wine. In California, a handful of large San Francisco merchants cornered the market and created a hierarchical organization, integrating horizontally and vertically and investing heavily in advertising and brands to sell to the East Coast merchants directly. This producers' organization, the California Wine Association, controlled at one time about 80 per cent of the State's wine sales, making it one of the world's largest wine businesses. By contrast, a British importer, Peter Burgoyne, created a buyer's organization that distributed two-thirds of Australian exports, and attempts by the South Australian government to create a state-led marketing board in London had only limited success. Although the Argentine industry was dominated by a dozen or so wine-makers, they suffered from weak brands as the Italian and Spanish 
immigrants were much less interested in quality than low prices. These firms, however, sold huge quantities of wine in a market where annual per capita consumption reached 60 litres by 1914, compared with just 2 litres in the United States and five in Australia.

This paper argues that the nature of demand was crucial in explaining the organization of the commodity chain and, with the exception of Australia, this was limited to the domestic market. Section 1 looks at some of the different theories to explain why firms integrate vertically rather than rely on market transactions and the nature and degree of asset specificity found in the wine industry. The next section shows how exogenous changes in the period between 1870 and 1914 changed traditional viti-viniculture and encouraged its rapid growth in the New World. The excellent grape growing conditions led to the appearance of specialist growers in the region, which, together with the growing economies of scale found in winemaking, changed the relative asset specificity of the vineyard and winery. The differences within the New World itself are then explained in the rest of the article. Sections 3 and 4 look at California and Australia, where beer and spirits were more popular among consumers than wine, and section 5 looks at Argentina, which enjoyed New World production conditions and a market with southern European consumer habits.

\section{FROM THE VINE TO THE GLASS: WINE'S VALUE CHAIN}

A number of distinct business activities were involved in the creation and sale of wines. Land had to be cleared, vineyards planted and growers had to wait 3 or 4 years before the first harvest. Grapes then had to be collected, crushed and the must fermented. The wines were then usually matured, blended and classified for sale and, when production took place at a distance from where they were to be consumed, transportation and distribution networks were also required.

These different activities made up the "value chain», but the wide diversity of wines produced could result in them being carried out by five or six separate business entities or being integrated into just one or two firms. This paper deals with cheap wines, especially beverage wines (vino común), which, in areas where wine consumption was an integral part of the national diet, such as Argentina, Italy, France or Spain, accounted for at least 90 per cent of production. It ignores the highly specific chains associated with fine table wines such as claret or champagne ${ }^{1}$. The production of vino común was organized very differently across countries. In Europe, grape growing and

1 In some fine wine regions such as Champagne or Burgundy, grape growing and winemaking were also often specialist activities. For a detailed discussion of these different chains, see Simpson (forthcoming). Centro Vitivinícola Nacional (1910, p. xx) and Pacific Rural Press (December 14, 1901, p. 372) for the very limited amount of fine wine produced. Cheap dessert wines (port, sherry) 
winemaking was integrated in a single, small family business, and marketing was carried out by merchants. In the New World, by contrast, grape production was a specialist activity, but winemaking and marketing were often integrated in the same firm.

In his classic article, Robert Coase explained organizational differences using what has become known as the transaction cost theory. For Coase, firms exist because the cost of organizing production for the entrepreneur is less than the cost of using the market mechanism (Coase 1937; Holmström and Roberts 1998, p. 73). The transaction costs associated with using the market relate to problems of information and commitment and, according to Holmström and Roberts (1998, p. 74), "the most influential work during the last two decades on why firms exist, and what determines their boundaries, has been centered on what has come to be known as the "hold-up problem»». This occurs when assets are highly specific and trading partners attempt «to appropriate some of the returns that the assets' owners expected when they invested in them»(Roberts 2004, p. 91). Vertical integration is predicted to be more likely "when assets are specific, when transactions are complex, and uncertainty is important» (Lafontaine and Slade 2007, p. 653) ${ }^{2}$. Three assets in particular are important for this paper: the vines, the winery and the brand names under which the wine was sold. This led to three areas where activities were either fully integrated or required vertical coordination (or «co-operation» as contemporaries called it): the link between the grape grower and wine-maker; that between the wine-maker and wholesalers; and finally in Australia between the exporter and (British) importer.

The development of commercial wine production in the New World from the 1890s presented small family growers with a major dilemma: whether to specialize in grape production with its associate dependence on the wine-maker, or to invest themselves in winemaking facilities, despite the increasing barriers to entry associated with the capital and knowledge requirements embodied in the new technologies. The possession of small private wineries offered growers some independence, but they faced both higher production costs and produced poorer quality wines than the new commercial wineries. These new wineries had a much larger capacity than the traditional ones and required grapes from the equivalent of perhaps twenty or thirty times what a family vine-grower could produce, presenting their owners with a strategic decision as to whether to integrate backwards into grape production or purchase from independent suppliers.

\footnotetext{
(F'note continued)
}

became increasingly important in Australia and the United States from the turn of the century, but these reinforced the changes described below for table wines.

2 See also Klein et al. (1998), Holmström and Roberts (1998) and Roberts (2004). 
Selling wines required other organizational decisions. In the first instance, New World producers were located far from a number of their major markets: the East Coast for California; the British market for Australia; and Buenos Aires for Mendoza. Second, in the first two countries, consumers were often unacquainted with wine, and producers had to compete with other alcoholic beverages. Finally, the widespread adulteration and fraudulent labelling of food and beverages in the late $19^{\text {th }}$ century was especially common with wine, which created considerable information asymmetries along the chain.

The question of who controlled and benefited from the value created varied according to the type of wine and the nature of the commodity chain. At one extreme, power in the value chains could be concentrated at two very different points (Gereffi 1994, p. 104). In agriculture, there are often literally millions of producers, with production carried out in many countries, making it easier for importers to dominate the trade by creating standardized products and investing in branding and marketing. By the late $19^{\text {th }}$ century, a few very large companies dominated a number of food and beverage buyer-driven commodity chains in the British and U.S. markets (Heinz, Quaker Oats, Cadbury, etc.) ${ }^{3}$. By contrast, producer-driven chains are controlled by core firms «at the point of production» and include such products as aircrafts and computers. Producer-driven chains are unusual with agricultural commodities, although the limited supply of topquality land and high production costs created barriers that allowed a highly specialized producer such as Moët \& Chandon to control its chain.

In fact, fine wines in $19^{\text {th }}$ century Europe were branded in a wide variety of ways, including that of the producer (e.g. Château Margaux), the shipper (Sandeman) or the retailer (Victoria Wine Company in the United Kingdom). By contrast, the major differences in quality found over relatively small geographical areas and from one harvest to the next made it almost impossible to create brands to sell cheap table wine in Europe. Instead, it was the retailer's reputation that determined consumer choice. In the New World, however, the much greater homogeneity of grape quality and the new winemaking technologies allowed, in theory, fully fermented quality table wines with similar characteristics to be consistently produced each year in large geographical areas, thus making the branding of ordinary table wines a realistic possibility. Who put the brand and controlled the value chain is discussed in sections 3-5 below.

\section{GRAPE GROWING AND WINEMAKING: A TALE OF TWO WORLDS}

In the mid- $19^{\text {th }}$ century, the wine industry in both Europe and the New World was small scale. By 1914, this was still generally true for Europe but

${ }^{3}$ For the difficulties in establishing buyer-driven commodity chains in the British wine market, see Simpson (2004). 
not so in the New World where large industrial wine producers dominated the sector. Four major exogenous events changed the industry during this half century: the integration of national and, to a lesser extent, international markets; the development of new political institutions and the ability of some pressure groups to solve collective action problems and mobilize political power; the appearance of new vine diseases and the production shortages they created; and advances in the knowledge of fermentation processes and development of winemaking equipment that produced economies of scale and allowed cheap table wines to be produced in hot climates. After discussing how each event influenced the business environment, the organization and growth of the New World industry is considered in detail.

Arthur Young $(1794$, pp. 2, 25) noted for France in the late 1780s that the cultivation of the vine depended «almost entirely on manual labour... demanding no other capital than the possession of the land and a pair of arms; no carts, no ploughs, no cattle» ${ }^{4}$. Vines were almost always worked by their owners, as entry costs were low, there were few economies of scale and the vine could be grown competitively on small plots of land marginal to other crops. Wage labour was rarely used because output was very sensitive to the quality and timing of labour inputs, and vines could be easily and permanently damaged if the pruning, plowing and hoeing operations were badly carried out (Galassi 1992, pp. 78-83; Hoffman 1984) ${ }^{5}$.

In Europe, the weather, pests and vine diseases influenced the size and quality of the harvest, especially in the colder and damper areas of the north. Wine was abundant and excellent one year but scarce or undrinkable the next. Grapes had to be processed quickly because they were easily damaged or diseased, and therefore family growers also made their own wine. Furthermore, although «fine» wines might improve with age, the great majority of table wines had a very short «shelf» life. Those that had been poorly made or stored quickly become diseased and undrinkable. In France, during the second half of the $19^{\text {th }}$ century, there were reportedly 1.5 million growers, but most families dedicated part of their labour and land to other activities because of the risky nature of production.

The demand constraints placed on the industry were significantly reduced during the second half of the $19^{\text {th }}$ century by a combination of cheap transport, urbanization and rising incomes. Railways helped push Europe's wine frontier southwards and allowed growers to specialize in the Midi (France), La Mancha (Spain) and Puglia (Italy), regions long known to contemporaries as being especially suitable for the vine. In France, for example, rising living standards led to consumption per capita increasing

\footnotetext{
${ }^{4}$ The version used here is the second chapter on «vines» of the Bury St Edmonds edition.

${ }^{5}$ Rental contracts were very rare as tenants might be tempted to increase short-term output at the expense of reducing the productive life of the vine, while sharecropping suffered from the high costs associated with dividing the harvest (Carmona and Simpson (2010)).
} 
from 76 litres in 1850-1854 to 108 litres in 1890-1894 and reaching 168 litres in 1900-1904 (Nourrisson 1990, p. 321). As the distance between the producer and consumer increased, so did the economic power of the merchants, who were able to purchase their wines over an increasingly large area. However, the nature of political institutions and the political voice of thousands of small producers also changed and, in France, this enabled them to achieve favourable legislation to establish cooperatives and regional appellations, helping producers to wrest back some of the market power from the merchants (Simpson 2005).

The growth in French consumption was all the more impressive because of the devastation wrought by the vine disease phylloxera, which in time killed most of the world's vines. The only permanent solution involved replanting and grafting European varieties on phylloxera-resistant American rootstock ${ }^{6}$. During the $19^{\text {th }}$ century, France was the country worst affected, and output fell from an average of 57.4 million hectolitres in 1863-1875, to 31.7 million in 1879-1892, before recovering to 52.5 million in 1899-1913. These phylloxera-induced shortages caused higher international wine prices and encouraged growers everywhere to plant vines and increase output ${ }^{7}$.

Although phylloxera and other vine diseases forced governments to increase expenditure on scientific research, the advances in winemaking were as spectacular as anything achieved in the vineyards ${ }^{8}$. In hot climates, fermentation had often ended prematurely, leaving sugar in the wines that made them unstable and ruining them. In 1887, Paul Brame successfully devised a system to reduce the temperature by pumping the must through tubes which were immersed in water. The last decade of the $19^{\text {th }}$ century and the first of the $20^{\text {th }}$ saw major investment in new wineries in hot climates incorporating the latest technologies such as refrigeration, continuous presses, aero-crushing turbines, sterilizers and pasteurizers, which helped create economies of scale in a number of important areas ${ }^{9}$. First, considerable skills were required to control the temperature of the must during fermentation, correct its acidity and use cultivated yeasts to produce a dry table wine which would keep. Second, new winemaking technologies and cellar designs helped cut labour costs, an important consideration in highwage economies such as those found in the New World. Third, more wine was extracted from the grapes. Fourth, merchants demanded large quantities of wines of uniform style that could be repeated each year, which was impossible for small producers to achieve. Finally, some of the large wineries

${ }^{6}$ For the history of phylloxera, see especially Campbell (2004), Paul (1996) and Pouget (1990).

7 For Spain, Pan-Montojo (1994); Italy Loubère (1978); and Algeria, Isnard (1954) and Birebent (2007).

8 Paul (1996) and Simpson (forthcoming), chapter 2.

9 Isnard (1954, pp. 189-190). For similar advances in Australia at this time, see Simpson (forthcoming). 
diversified into distilling and the production of brandy and fortified wines where the economies of scale were even greater.

These new winemaking technologies led to a shift in the locus of production of cheap table wines from Europe's centre to its southern periphery. In particular, France's four Midi departments (Aude, Gard, Hérault and Pyrenees Orientales) and Algeria saw their output increase from the equivalent of less than 15 per cent of domestic consumption in the 1820 s to 50 per cent by $1910^{10}$. The new technology was also crucial for the expansion of New World viticulture. In California, wine production increased fourfold between 1891-1893 and 1911-1914, and in Mendoza the area of vines increased from 22,875 hectares in 1904 to 57,764 in 1912, and output jumped fourfold in the decade after 1904 (Table 1). By contrast, in Australia the new technologies helped capture new export markets rather than increase output (Osmond and Anderson 1998, p. 41).

The new wineries required large quantities of grapes and offered the greatest returns to producers in hot climates, which explains why they were rare in much of Europe. As late as 1934, some 86.5 per cent of all French wine production outside the Midi was still found in wineries producing less than 400 hectolitres, a quantity that could be supplied from many family vineyards (Galet 2004, calculated in Simpson, forthcoming). By contrast, in the New World, and to a lesser extent in Algeria and some parts of the Midi, large wineries dominated production by the early $20^{\text {th }}$ century ${ }^{11}$. Some of the New World wineries had a considerably greater capacity than 10,000 hectolitres. In Mendoza, the ten largest firms produced 445,000 hectolitres or a third of the output, while in South Australia the figure was more than two-thirds, although this was a relatively modest 78,000 hectolitres (Tables 2 and 3) ${ }^{12}$. In Mendoza, the number of firms producing more than 10,000 hectolitres jumped from 18 to 96 between 1900 and 1914 when the three largest firms produced 350,000 hectolitres, requiring grapes from about 6,000 hectares (Barrio de Villanueva 2009, pp. 5-7) ${ }^{13}$. In California, the Italian Swiss Company (owned by the California Wine Association) produced 225,000 hectolitres from eight different wineries in 1911, while the California Wine Association's huge «Winehaven» complex in Richmond had storage for 378,000 hectolitres

${ }^{10}$ Algeria became an integral part of France after 1848, and Algièrs, Oran and Constantine were organized as French départements.

${ }^{11}$ In the Midi, there were 130 wineries by 1903 with a minimum capacity of 10,000 hectolitres each, the equivalent of one for every 180,000 hectolitres of wine produced, implying that smaller wineries remained very much the predominant form of production. In Algeria, there were 53 large wineries, equivalent to one for every 145,000 hectolitres, while in Mendoza the figure was 34 wineries, and one for every 40,000. Gervais (1903), my calculations and Barrio de Villanueva (2008a cuadro 1). The Midi's harvest is taken as 23.4 million hectolitres for this year.

12 Four of these Mendoza firms had two wineries. Ibid. (cuadro 1) and for South Australia, Whitington (1903, p. 71)

13 A yield of 60 hectolitres per hectare is assumed. 
TABLE 1

LEADING WINE PRODUCING COUNTRIES BEFORE 1914

\begin{tabular}{|c|c|c|c|c|}
\hline \multicolumn{4}{|c|}{ Wine production in millions of hectolitres } & \multirow[b]{2}{*}{ Per cent of total in 1909-13 } \\
\hline & $1865-74$ & $1885-94$ & $1909-13$ & \\
\hline France & 55.4 & 31.9 & 46.4 & 31.4 \\
\hline Italy & 23.6 & 31.9 & 46.0 & 31.2 \\
\hline Spain & 17.1 & 21.9 & 14.9 & 10.1 \\
\hline Austria-Hungary & 3.2 & 7.7 & 7.9 & 5.4 \\
\hline Portugal & 2.1 & 4.3 & 4.8 & 3.3 \\
\hline Greece & 0.2 & 1.8 & 3.2 & 2.2 \\
\hline Germany & 2.5 & 2.5 & 1.8 & 1.2 \\
\hline Russia & 3.3 & 3.5 & $1.4 *$ & $0.9 *$ \\
\hline Rumania & 0.1 & 2.8 & 1.4 & 0.9 \\
\hline Bulgaria & & & 0.8 & 0.5 \\
\hline Other European & & & 0.9 & 0.6 \\
\hline European total & & & 129.5 & 87.8 \\
\hline Algeria & 0.2 & 3.1 & 7.9 & 5.4 \\
\hline Argentina & n.a. & n.a. & 4.4 & 3.0 \\
\hline Chile & n.a. & n.a & 2.0 & 1.4 \\
\hline United States & 0.3 & 1.0 & 1.9 & 1.3 \\
\hline Russia (Asia) & & & 0.9 & 0.6 \\
\hline South Africa & 0.7 & 0.3 & 0.3 & 0.2 \\
\hline Tunisia & & & 0.3 & 0.2 \\
\hline Australia & n.a & 0.1 & 0.2 & 0.1 \\
\hline Other countries & 5.1 & 15.7 & 0.2 & 0.1 \\
\hline Non-European producers & & & 18.1 & 12.3 \\
\hline World & 113.7 & 125.7 & 147.6 & 100.0 \\
\hline
\end{tabular}

*Refers to European Russia.

Sources: 1865-74 and 1885-94, Morilla Critz (1995, p. 303); 1909-13 International Institute de Agriculture: 1913 and 1914 (1915, pp. 110-111); and Mitchell (1995, p. 240). Except Portugal, Lains and Sousa (1998, p. 965); Argentina, Boletín del Centro Vitivinícola, various issues and Barrio de Villanueva (2009, p. 10); Australia, Osmond and Anderson (1998), Table 1; United States: Shear and Pearce (1934; Table 10). 
TABLE 2

LEADING WINE-MAKERS IN SOUTH AUSTRALIA, 1868, 1876 AND 1903

\begin{tabular}{|c|c|c|c|c|c|c|}
\hline & \multicolumn{2}{|c|}{1868} & \multicolumn{2}{c|}{1876} & \multicolumn{2}{c|}{1903} \\
\hline Vineyards & $\begin{array}{c}\text { Quantity } \\
\text { produced }\end{array}$ & $\begin{array}{c}\text { Per cent } \\
\text { of SA } \\
\text { production }\end{array}$ & $\begin{array}{c}\text { Quantity } \\
\text { produced }\end{array}$ & $\begin{array}{c}\text { Per cent } \\
\text { of SA } \\
\text { production }\end{array}$ & $\begin{array}{c}\text { Per cent } \\
\text { Quantity } \\
\text { produced }\end{array}$ & $\begin{array}{c}\text { SA } \\
\text { production }\end{array}$ \\
\hline $\begin{array}{c}\text { Largest } \\
\text { three }\end{array}$ & 1,637 & 4.4 & 4,546 & 20.3 & 42,960 & 37.0 \\
\hline $\begin{array}{c}\text { Largest } \\
\text { five }\end{array}$ & 2,546 & 6.9 & 6,428 & 28.7 & 57,962 & 49.9 \\
\hline $\begin{array}{c}\text { Largest } \\
\text { ten }\end{array}$ & 5,231 & 14.2 & 9,966 & 44.4 & 78,191 & 67.4 \\
\hline $\begin{array}{c}\text { Total state } \\
\text { vintage }\end{array}$ & 36,919 & & 22,422 & & 116,082 & \\
\hline
\end{tabular}

SA, South Australia.

Quantities in hectoliters.

Sources: Bell (1993; Table 3) and Whitington (1903, p. 71).

TABLE 3

LEADING WINERIES IN MENDOZA, 1903

\begin{tabular}{|l|c|}
\hline Tomba y hijos & 91,150 hectolitres \\
\hline Gio y Gargantini & 58,235 \\
\hline Balbino Arizu hijos & 57,022 \\
\hline Testentaría Honorio Barraquero & 54,754 \\
\hline Germania S.A. & 38,614 \\
\hline Borel y Calise & 36,153 \\
\hline Miguel Escorihuela (two wineries) & 34,646 \\
\hline Trapiche S.A. (two wineries) & 22,784 \\
\hline
\end{tabular}

Source: Diario El Comerico (October 27, 1903, p. 2) cited in Barrio de Villanueva (2008a, cuadro 1).

(equivalent to about 25 per cent of California's output), and it had winemanufacturing facilities for 140,000 hectolitres ${ }^{14}$.

There were few economies of scale to be exploited with grape growing, and therefore family producers remained competitive everywhere. However,

14 Peninou and Unzelman (2000, p. 104). Another California company, the Italian Vineyard Company, had 2,000 hectares of vines and wineries with a capacity of almost 20 million litres (Pinney 1989, p. 362). 
while in the Old World grape and wine production remained integrated, in the New World they were often specialist activities by $1900^{15}$. In California, the Pacific Wine and Spirits Review noted that most growers sold their grapes to wine-makers, "except to a limited extent in some of the older districts", whereas previously nearly every vineyard had had its own fermenting house and storage cellar. Thomas Hardy, a leading producer in South Australia, wrote as early as 1882 that «the manufacture of wine is now almost wholly gone into the hands of those who make a business of it, and do not follow it merely as a secondary pursuit» ${ }^{16}$, while in Mendoza producers bought around three-fifths of their needs from specialist grape growers by 1908 (Centro Vitivinícola Nacional 1910, p. 17).

These organizational differences between Europe and the New World can be explained by the nature of and the changes in the asset specificity of vineyards and wineries. In Europe, grapes had to be processed very quickly, especially if they were diseased, and growers could not risk having to find buyers at short notice. By contrast, in the New World climatic conditions made the vines much easier to grow, harvest failures and disease were rare, and the grapes were of a consistent quality with high levels of sugar ${ }^{17}$. Growers in California and Australia sometimes produced the "three way» grape, allowing them to decide after the harvest whether to sell them for wine, raisins or the table, while in Argentina growers could leave their grapes on the vines for 3 or 4 months before selling them (Pacottet 1911, p. 78).

This suggests that specialist grape growers in the New World were less vulnerable than winery owners to problems of hold-up, despite the fact that the latter frequently colluded to set prices. This was especially true in Australia and California because of the better quality wines they produced, as wine-makers needed a guaranteed supply of adequate grapes when markets recovered. Possibilities of exit were also easier to growers than to winemakers, as alternative and often attractive employment opportunities were available nearby in the large, diverse economies of San Francisco and Melbourne. Mendoza, by contrast, was a thousand kilometres from Buenos Aires, but the growers here benefited from significantly greater yields

15 This was generally true even in the Midi (and Algeria), where the new winemaking technologies produced what one writer termed la viticulture industrielle Augé-Laribé (1907). For a discussion on how transaction costs associated with using wage labour on wine estates was reduced, see Simpson (2005).

16 Pacific Wine \& Spirits Review (December 1906, p. 43) and Aeuckens (1988, p. 148). By 1900 , for example, Hardy's had 500 acres of vines and brought grapes from 500 or 600 more, the property of some thirty or forty independent growers. Hardy also noted that «I reckon we have done more in advancing the science of winemaking during the last 5 years than we did in 20 years before» Victoria (1900, pp. 38-39).

17 In Victoria, for example, new vines became productive after 3 rather than the 4 or 5 years in Europe, and the hot climates reduced considerably the incidence of vine disease (and consequent expenditure on chemicals), and allowed high-quality grapes rich in sugars to be produced each year (Castella 1886, p. 17). 
because of irrigation, and market downturns, at least prior to 1914 , were short so that many growers carried low levels of debt ${ }^{18}$.

The separation of grape growing and winemaking nevertheless created new coordination problems. Market volatility was common in all wine regions because if high prices encouraged the planting of new vineyards, market conditions might be very different when these became productive 3 or 4 years later. The high fixed costs along the commodity chain implied that grape prices in Mendoza, for example, could double or halve from one harvest to the next, while wine prices in Buenos Aires fluctuated much less (La Prensa, 12 abril 1914, p. 11). The fact that grape production and winemaking were usually integrated in a single business in Europe resulted in producers expanding capacity in both areas in response to market upturns. In the New World, growers and winery owners faced different investment incentives. The creation of new vineyards required relatively little capital and smallholders could plant vines working during periods of low seasonal demand for wage labour. By contrast, the high capital cost of the new wineries implied that investment was linked to credit availability. This separate ownership of vines and winemaking facilities often led to unbalanced growth between the two sectors, because if large wineries failed to purchase grapes from independent producers because of low prices, growers could crush them themselves so that aggregate wine supply was not diminished, although quality dropped. Therefore, the new capital-intensive wineries required not just a secure supply of grapes, but also a market for their wines.

Another major problem was fraud. Fraud had always been present in food and beverage markets, but it changed significantly over the second half of the $19^{\text {th }}$ century because of the growing physical separation between producers and consumers and the development of new preservatives that allowed manufacturers to mask food deterioration and lower costs, often making food adulteration imperceptible to consumers. As Marc Law and Gary Libecap note $(2006$, p. 321), science increased the complexity of products and «created opportunities for cost-saving deception by some firms through adulteration of their products in ways that consumers could not easily perceive». Firms were naturally reluctant to invest capital in state-of-the-art winemaking facilities, brand names and advertising if they were going to have to compete with "wines» made from a variety of concoctions and sold in «fancy bottles» at considerably lower prices.

Finally, although the flow of ideas and technology across national borders was increasing in 1900, international wine trade was limited, especially after French growers replanted after phylloxera. As Table 4 shows, tariffs everywhere were high compared with average wine prices in France because taxes

18 La Prensa (10 abril 1914, p. 9), for example, noted that the new growers suffered most as their vines had just started producing. Sharecroppers (contratistas) were also partly protected because they received a fixed salary. 
TABLE 4

LEVEL OF TARIFFS ON WINE IMPORTS, 1898

\begin{tabular}{|l|c|}
\hline & Francs per hectolitre \\
\hline New South Wales & 138 \\
\hline Victoria & 165 \\
\hline South Australia & 165 \\
\hline United Kingdom & 28 \\
\hline Argentina & 40 \\
\hline Chile & 125 \\
\hline France & 20 \\
\hline Italy & 20 \\
\hline Spain & 50 \\
\hline United States & 55 \\
\hline French wine price (1896-99) & 26 \\
\hline
\end{tabular}

Figures are for ordinary red wine. The French figure ranges from 12 francs for wines of up to 10 degrees alcohol, to 20 francs for those of 15 degrees.

Sources: Cocks and Féret (1898, pp. 775-784); for France: Sempé (1898, p. 196) and France annuaire 1938 (1939, pp. 62-63).

on all types of alcohol were a major part of national (and often local) revenue. Most countries preferred to use excise taxes on domestic output rather than encourage imports to provide these revenues, which would also have led to greater competition for domestic producers of alcoholic beverages. The new industries in both Argentina and California were therefore able to benefit significantly from import substitution, although this was not the case in Australia where domestic demand for wine was always very small (Figure 1 and Table 5).

\section{CALIFORNIA}

There were four major players in the Californian wine industry in the late $19^{\text {th }}$ century: grape producers, wine-makers, San Francisco shippers and the East Coast bottlers and distributors ${ }^{19}$. The rapid growth of the national market demanded coordination between businesses so that the high levels of capital investment in vineyards and winemaking equipment were not left

19 This section is a summary of Simpson (2008). 
FIGURE 1

IMPORT SUBSTITUTION AND SELF-SUFFICIENCY IN WINE

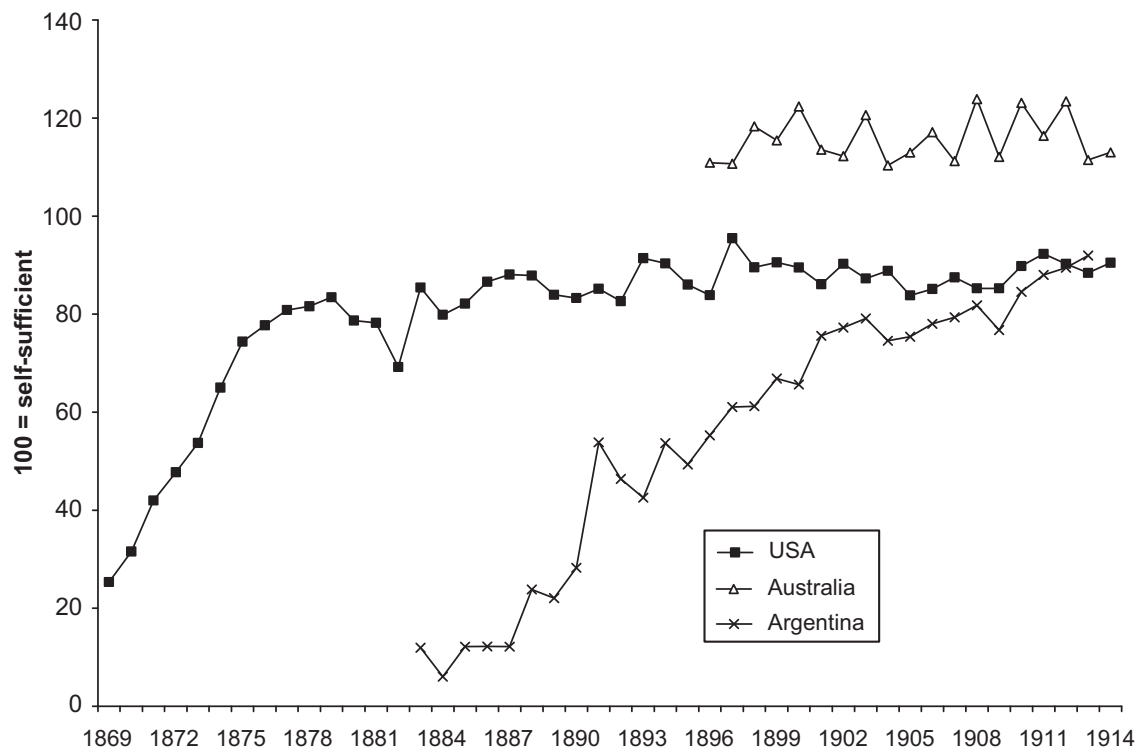

Notes: $>100$, Countries export more than they import; $<100$, they import more.

Sources: see Table 5.

idle. Faced with falling prices and widespread adulteration of wines, the small wine makers established the California Wine-Makers Corporation (CWMC) in 1894 which entered into a 5-year agreement to sell their wine to the California Wine Association (CWA), another combine created in the same year by the leading West Coast wine dealers. By 1897, the CWMC represented 80 per cent of California's wine-producers while the CWA had 80 per cent of the wine (Peninou and Unzelman 2000, p. 79). However, postcontractual opportunistic behaviour led to a "wine war» between the two organizations, with the CWA supposedly refusing to pay the prices previously agreed and the CWMA selling large quantities of wine directly to a New York merchant rather than through the San Francisco merchants in violation of its contract. After its legal defeat in 1899, the CWMC disappeared, leaving the field to the $\mathrm{CWA}^{20}$. According to a recent study, between 1894 and Prohibition the CWA would «cultivate more vineyard acreage, crush more grapes annually, operate more wineries, make more wine and have a greater wine

${ }^{20}$ Attempts to establish another growers' combine to control a minimum of 80 per cent of the crop also failed. Pacific Rural Press (July 8, 1899, p. 30). 
TABLE 5

DOMESTIC PRODUCTION, TRADE AND CONSUMPTION, 1909-13

\begin{tabular}{|l|c|c|c|c|c|}
\hline & Production & Imports & Exports & $\begin{array}{c}\text { Domestic } \\
\text { consumption }\end{array}$ & $\begin{array}{c}\text { Per capita } \\
\text { consumption litres/year }\end{array}$ \\
\hline Argentina & 2,937 & 426 & & 3,363 & 48.5 \\
\hline Australia & 246 & 6 & 41 & 211 & 4.7 \\
\hline United States & 2,005 & 280 & & 2,248 & 2.4 \\
\hline
\end{tabular}

Figures in thousands of hectolitres, except per capita consumption.

Sources: Argentina and Australia (Table 1); California, Shear and Pearce (1934; Table 6).

storage capacity than any other wine concern in the world» (Peninou and Unzelman 2000, p. 33) ${ }^{21}$. This was horizontal consolidation and vertical integration - from grape growing to distribution - on a massive scale and led André Simon (1919, p. 105) to write that «in the old world, winemaking is an art; in America, it is an industry».

Consolidations to escape price competition were common in the United States in the capital-intensive, mass-production industries in which «firms were closely matched and in which expansion had been rapid on the eve of the Panic of 1893» (Lamoreaux 1985, pp. 45 and 87). The heterogeneity of wine makes the possibilities of collusion in the wine market difficult, but by integrating forwards and controlling distribution, the CWA was able to guarantee that the wine was not adulterated. This provided not only the necessary market stability for it to invest in brand names but also a guarantee for consumers that the wines were not adulterated ${ }^{22}$. The objective of the CWA was not to produce fine wines but to develop a mass market for stable and unadulterated ones, which it could sell to American consumers under the protection of high tariffs. As Amerine and Singleton (1976, p. 286) would later write, the company «never sold a bad bottle of wine», but neither did it sell a "great bottle». Percy Morgan, who for many years was the CWA's chairman, noted in 1917 that forward integration helped create new markets for California's wines:

Until the coming of the California Wine Association only a few wineries tried to deliver their original packages direct to the consumer and build up a following for their label. The large dealer almost always sold California wines in bulk to distant jobbers who either bottled them with a domestic or foreign label known to their particular

21 However, Percy Morgan himself recognized the advantages of small, independent grape producers (Morgan 1902, p. 95).

22 Wines were sold under labels such as Brun \& Chaix, De Turk, Greystone, Italian Swiss Colony (Pinney 2005, p. 8). 
localities, or sold them to retailers who pursued a similar course. Moreover, these distributors and retailers had neither the knowledge not the facilities to age and handle wines properly. Only a large firm with capital could select from millions of gallons, blend to standards, market under labels that could gain the confidence of the public, and stand back of the label wherever sold (cited in Peninou and Unzelman 2000, p. 125).

There is little doubt that the CWA used its market power to fix grape and wine prices, but the rapid growth in the industry between 1894 and 1914 also suggests that all sectors of the industry benefited. Indeed, family growers in California probably suffered less during the turbulent 1900s than any other wine-growing region in the world, and the CWA's dependence on them was recognized by Percy Morgan:

... it is not from these great tracts that the larger portion of the tonnage for wine purposes will be derived. It is from the small vineyardist, cultivating from ten to fifty acres (four to twenty hectares); cultivating and looking after his lands individually, and thereby obtaining from 30 per cent to 50 per cent more tonnage to the acre than is possible from the great vineyard tracts, that the very remunerative results will accrue $^{23}$.

In conclusion, the heavy investment by the CWA in production facilities and brands raised the entry costs for independent wine producers. Limited competition came from a handful of small independent wineries which began to specialize in fine wines in the Napa region, while at the other extreme San Francisco's Italian community sometimes preferred to buy grapes which they used to produce home-made wines, a practice which became even more important under Prohibition, when the area of vines actually doubled (Lapsley 1996, pp. 67-68; Heintz 1990; Pinney 2005, p. 18) ${ }^{24}$. Competition to the CWA came from the large breweries and distillers rather than from other wine producers. California's wine production increased by a factor of four between 1891-1893 and 1911-1994, but while dessert wine production multiplied ninefold, that of dry table wines rose by just a third (California State Agricultural Society 1915, p. 139). Dessert wines were less likely to deteriorate, whether left on retailers' shelves or in consumers' decanters, and because they were often sweet, found greater acceptance among North European immigrants. For the CWA, there were important economies of scale, especially in creating large batches of homogeneous wines to brand and fortifying wines using domestic grape brandy, which

${ }^{23}$ Morgan (1902, p. 95) reproduces an earlier article in the Sacramento Bee.

${ }^{24}$ Under Prohibition, it was illegal to sell wine but not to possess or consume it. 
avoided the $\$ 1.10$ a gallon brandy tax. This made fortified wines the cheapest form of alcohol in the market, allowing the CWA to distil their poorer wines profitably and compete with other alcoholic beverages (Seff and Cooney 1984, p. 418).

\section{AUSTRALIA}

The Australian wine industry was the only one in the New World with an important export trade, accounting for about a fifth of national production in the period 1909-1913 and with virtually all being sold to the United Kingdom (Australian Vigneron, March 1902, p. 236). The high quality of these dry, unfortified red wines allowed them to be marketed using brand names, a feature virtually unknown among European producers of vin ordinaire. However, the quantity of wine involved was relatively small, peaking in 1902 at 4.5 million litres, equivalent to just half the output of Argentina's largest producer at this time.

In California, the high entry costs to marketing wines on the U.S. East Coast before Prohibition were reduced by the CWA, as a producer-led commodity chain. By contrast, it was a market-led chain which was created to sell Australian wines in London ${ }^{25}$. Australia's high internal tariffs before Federation in 1901 made commercial producers look to the British market some 20,000 kilometres away, even though freight costs were approximately three times greater than those facing French exporters ${ }^{26}$. In addition, the long sea voyage and the extremes in temperature meant that all wines, especially the young ones and those «that have not been thoroughly well made», underwent a "very considerable and detrimental change» (Australian Vigneron, July 1892, p. 47). Imported wines required several months' rest on their arrival and faulty or young wines were often permanently ruined. These quality changes caused major problems for the trade. One prominent London West End merchant, who reportedly imported sixty hogsheads of South Australian wine because of its growing popularity, claimed it was so «ill-fermented» that he resolved never to import any more direct from Australia (Australian Vigneron, October 1893, p. 114). For this particular late $19^{\text {th }}$ century market to work, trusted agents were required at both ends of the chain: in Australia to check that only well-made wines were shipped; and in London to determine the appropriate remedies to correct the wines on their arrival.

Trade was dominated by two major London houses that specialized in Australian wines: Walter Pownall, and in particular Peter Burgoyne, who

25 At this time, Australia exported dry red table wine referred to as a "Burgundy type», somewhere «between the heavily fortified wines on the one hand, and light wines, such as clarets and hocks on the other» to the United Kingdom. Australian Vigneron (March 1902, p. 236).

26 Ibid. (July 1892, p. 48). Victoria (1900, p. 12) for Australia's internal tariffs. 
claimed in 1900 that over the previous 30 years «fully 70 per cent of the wine exported from Australia to England had passed through his hands» (Australian Vigneron, September 1900, p. 115). In 1893, Burgoyne bought the Mount Ophir vineyard (Victoria), and investment in new wine-making facilities from the turn of the century led one commentator to report that «it would be difficult to find in any part of the world a winery in which California labor saving appliances and the most approved European methods of securing the best treatment of the wine are so completely adopted». Large quantities of grapes and wine were brought also from other producers to be blended to create a standard product that was exported after 19 months. Burgoyne's agents selected wines in Australia, while in London the firm had around 4500 hogsheads of wine in bond and a similar quantity at the Pelham Street premises in 1912. Wines were sold by the cask and the bottle using the Ophir (Burgoyne) and Emu (Pownall) brands. "Burgoyne's Australian Wine» placards were found "on every railway station in England», and the company claimed to have invested $£ 300,000$ in advertising. The chain was completed when, from the turn of the century, Burgoyne started a retail trade in Australia itself (Simpson forthcoming).

The rapid advances in these winemaking technologies, the stranglehold enjoyed by Burgoyne over the British market, the slow growth of the industry and the large quantity of poor wines still being produced ${ }^{27}$ led to both the South Australian and Victorian governments holding parliamentary enquiries into how to organize the industry at the beginning of the $20^{\text {th }}$ century. In particular, they discussed the potential advantages of establishing district cooperative wineries for small growers, «central cellars» in Adelaide and Melbourne to blend and create standard wine types, and a London depot to compete directly with Burgoyne. We shall look at each very briefly.

The separation of growing and winemaking activities was less apparent outside South Australia $^{28}$. In Victoria, production was small scale, and 2,382 growers cultivated just 1,123 hectares of vines in 1900, with just 72 holdings larger than 20 hectares (Victoria 1900, p. 5). Many of these growers had responded to the State incentives of a $£ 5$ bonus payment per hectare to plant

27 Contemporaries distinguished between two types of wines being produced - «very good red, full-bodied wines» for export, and poorly made, often diseased and fortified wines for the domestic markets. See, for example, Victoria (1900, pp. 33, 34 and 38).

28 The advantages of vertical integration were hotly debated, and Arthur Perkins, the Government Viticulturist for South Australia, spoke of «two separate classes with antagonistic interests vignerons on the one hand, wine-makers on the other», and suggested that this was the cause of the slow growth of the State's viticulture. Australian Vigneron (January 1899, p. 169). By contrast, Raymond Dubois, the Principal of the Viticultural College at Rutherglen in Victoria, argued that only the new winemaking technologies could produce quality table wines, and the State's poor wines were the result of using poor equipment and production methods on small vineyards, and Romeo Bragato, the Victorian Government's viticultural expert, reported that "one of the chief drawbacks of the industry ... is the fact that a man who grows grapes thinks he can also make wine» (Victoria 1900, pp. 21, 33). 
vines, but their lack of wine-making skills and capital resulted in poor quality wines being produced. Growers planted vines but did not build cellars and attempts at creating four subsidized district wineries failed, largely because there were few incentives for growers to improve quality. These were not cooperatives where growers provided their own capital and took responsibility themselves for rejecting substandard grapes or wine, as was the case with the Danish dairy cooperatives at the time (Henriksen 1999). However, while district wineries failed to encourage producers to improve product quality, their presence provided competition to private wine businesses that strongly opposed them ${ }^{29}$.

The control of the British market by Burgoyne was also deeply resented by many, and as early as 1894, the South Australian government created a wine depot in London to provide an alternative outlet for domestic producers. The depot did not legally own the wines, so it could not blend them to create homogeneous products in sufficient volume to brand and instead had to match each individual shipment with a different purchaser. The depot's manager therefore entered into an agreement with a London merchant to sell the wine, which resulted in considerable opposition from Burgoyne and the London trade press and led to a trade boycott by merchants in the United Kingdom ${ }^{30}$. Although the depot claimed to have sold South Australian wine to over 4,000 customers by 1900 , «including most of the best wholesale houses in London and the provinces, large wine merchants and grocers, as well as a number of high-class restaurants and clubs», and sales increased threefold over 5 years, these remained just a fifth of what Burgoyne handled (South Australia 1901, p. iii). Burgoyne responded to the debates over the depots in 1900 and 1901 by threatening to buy wines only after their arrival in London rather than in Australia, thereby passing more of the risk onto the domestic producers. The leading producers were forced to back down, the South Australia depot was wound up and Victoria's never established. In 1911, Burgoyne (2.7 million litres) and Pownall $(750,000)$ still dominated exports from South Australia and Victoria, although the British retailer Gilbey $(625,000)$ was now in a close third ${ }^{31}$. Although just as in California, in the domestic market the large Australian producers became increasingly interested in dessert wines after 1900 because of the production and marketing advantages that they offered.

\footnotetext{
29 Victoria (1900), see especially the reports by Thomas Blayney and Rome Bragato.

30 South Australia (1901, pp. 68, 2297). Thomas Hardy noted that «the large buyers would not touch the depot». By 1900, it had lost $£ 26,000$ «mainly in connection with the wine trade». Ibid. (p. iii).

31 Australian Vigneron (1912 January, p. 25 and February, p. 71). Figures are only approximate. The attempts by both Gilbey and Lipton, the giant British retailer with a reportedly 3,000 outlets, to obtain financial backing from the Victorian government in exchange for establishing a depot in Melbourne to collect wines for the British market were unsuccessful.
} 


\section{ARGENTINA}

The population of Argentina multiplied fivefold to eight million in the half century before 1914, with a high percentage being immigrants or their descendants originating from Italy, Spain or France. Many potential consumers, then, were already accustomed to drinking wine rather than beer or spirits. Growing conditions for grapes in Mendoza, which accounted for four-fifths of the nation's production in 1902-1903, were exceptional. Once the region had been connected by rail with Buenos Aires (1884) and wine-makers had learnt the art of fermenting their wines properly in the hot climate, the possibility of firms selling large quantities of good quality branded wines in a rapidly growing market appeared endless. With the exception of Algeria, Argentina's wine industry grew more and faster than anywhere else in the world between 1885 and 1914. Yet contemporaries found little to praise as the industry suffered two major recessions in a decade in the early $20^{\text {th }}$ century. Wine quality remained poor and per capita wine consumption was less than half the figure found in France.

The 1901-1903 crisis highlighted a number of structural problems facing the industry. Most of the wine produced and consumed in Argentina was strong, young, coarse and inferior to those produced in Australia or California $^{32}$. Pioneers of change, such as Eugene Hilgard or George Husmann in California, or Thomas Hardy and Arthur Perkins in South Australia, had no equivalents in Mendoza. However, just as in France, Italy or Spain, Argentina's producers were responding to a different type of market, one in which consumers' preference was for strong, cheap wines. The industry was dominated by a dozen or two large firms at the time, with the Tomba winery being the largest producing 91,250 hectolitres (almost 7 per cent of Mendoza's total), and equivalent to approximately 1,500 hectares of vines in full production, followed by the Giol y Gargantini winery with 58,255 hectolitres, and Arizu with 57,022 hectolitres. The large wineries reacted to the collapse in demand in 1902 by refusing to buy grapes from small producers, who were forced to open old cellars and sell their wine immediately after fermentation because of their lack of credit and storage facilities ${ }^{33}$. As a result, supply was not diminished and the poor quality of many wines made adulteration easy. Unlike producer countries in Europe, a high share of Argentina's production was concentrated in a single geographical area,

32 For example, while Australia was sending unfortified wines to Britain, an Argentine commission discussed whether spirits needed to be added when wines were sent to Buenos Aires. Arata et al. (1904). Wines were rarely matured for more than a month or two and virtually all were sold within the year. Kaerger (1901) cited in Barrio de Villanueva (2009, p. 169). See also Simois and Lavenir (1903, p. 127) and Arata (1903, p. 202).

33 There were reportedly 1,742 wineries in operation in 1902 compared with 1,082 in 1899 , and 1,010 in 1907. Barrio de Villanueva (2009 cuadro 6). For the presence of small wineries in California, see Pinney (1989, p. 362). 
which resulted in the leading producers having considerable political backing from Mendoza's provincial government, but much less from national politicians. The collapse in prices, the abysmal quality of the wines in 1902 and the threat of some politicians in Buenos Aires to reduce tariffs on Chilean wine imports pushed the large producers and local government into action, and a national commission was created to investigate the industry's problems. It included provisions for inspecting wine cellars and resulted in the destruction of diseased and adulterated wines ${ }^{34}$.

The difficulties facing the industry led to some large producers contemplating not just the creation of an independent regulatory agency to control adulteration, but also a trust that would restrict supply by buying surplus wines when necessary ${ }^{35}$. However, there were major obstacles to the creation of a wine trust such as California's CWA, not because the institutional regime in Argentina was so different from that in the United States, but rather because wine was considered by national politicians as a basic part of the labourers' diets ${ }^{36}$. Opposition to a monopoly therefore came not just from grape growers, but also from politicians in Buenos Aires who from time to time threatened to reduce tariffs on Chilean "pure wines" in exchange for allowing livestock exports ${ }^{37}$. Higher prices caused by a monopoly would also have threatened Mendoza's comparative advantage because it would have encouraged viticulture in other states, just as Mendoza's high taxation did in the interwar period. Finally, a trust which did not include all the major wineries risked problems associated with public goods and the free rider, namely independent local producers who did not contribute to the costs of regulating the market, increasing their output to benefit from the higher prices. The Argentine industry had low entry barriers because of the poor quality of most wines. By the autumn of 1903, the promise of higher grape and wine prices following the February harvest ended the debates, and the industry enjoyed another decade of rapid growth.

Wine quality undoubtedly improved in the first decade of the $20^{\text {th }}$ century, but producers lacked the market discipline found in Australia and California of having to sell to occasional, rather than habitual, wine drinkers. A handful

34 Elías Villanueva was Mendoza's provincial governor and the eleventh most important wine producer, and when his manager refused permission for the destruction of 1,000 hectolitres of spoilt wine, this led to a second visit by the Commission, when some 500 hectolitres were finally removed. See especially Barrio de Villanueva (2008b, p. 336).

35 For the various projects discussed, see especially Barrio de Villanueva (2006, pp. 190-198) and Mateu (2007, pp. 14-15).

36 In the wider Argentine economy, as in the United States, industrial supply «moved towards «trustification»..., capital concentration and big business» during the first decade of the $20^{\text {th }}$ century (Rocchi 2006, p. 9).

37 The leading Mendocino newspaper described a trust as both «ridiculous» and «impossible» Los Andes, (21 August 1901, p. 4), while the Buenos Aires newspaper, La Nación, warned of the dangers of a "cooperative» organized by «speculators» among wine producers, which claimed to protect the interests of the industry, consumers and government. Ibid. (January 15, 1903). 
of firms did begin to sell branded wines before 1900, and the number increased to 36 during the first decade of the new century ${ }^{38}$, resulting in a much greater percentage of ordinary table wines being sold under producer names in Buenos Aires than in Paris or Madrid. As one contemporary noted, unlike France there was no strict division between industry and commerce, and Mendoza's large wineries used their own intermediaries to sell their wines directly to consumers in the large centres of consumption (Alazraqui 1911, p. 85$)^{39}$.

Despite the growing use of brands, contemporaries bemoaned the fact that there was little to distinguish between the wines of the major producers, in part because of the widespread use of the malbec grape variety ${ }^{40}$. Product uniformity and collusion between the leading producers led to minimal price differences between the leading houses, although brands did offer some guarantee that it would be the consumer, rather than an intermediary, who added the water. Table 6 lists some of the leading wineries and their brands and shows that these were sold in Mendoza for about a third more than the "vinos de traslado». These were wines produced in small wineries by independent growers and sold immediately after fermentation to be blended with the produce of the big houses to meet their orders. The large wineries therefore adjusted their supply to meet the demand for their branded wines in the final market both through grape and wine purchases. Unfortunately, the golondrinas did not drink branded wine in Italy, and they were unwilling to pay a high premium for it in Argentina ${ }^{41}$.

After a decade of rapid growth, exogenous factors led to a fall in GDP of 10 per cent and the overnight disappearance of credit facilities. Once again, Mendoza's large wine producers failed to buy grapes from independent producers who reopened wineries and flooded the Buenos Aires market with wines that were still «hot» after fermenting, leading to a collapse in prices for both branded and unbranded products. The leading wineries tried to shift the adjustment costs to other sectors. Attempts to control wine prices failed, both because of the problems of free riders, but also because higher wine prices fed back into higher demand for grapes and led to a renewed growth in planting and even greater overproduction a few years later. Instead, leading

38 Barrio de Villanueva (2003, pp. 39, 42) and Richard Jorba (1998, p. 306). One of the functions of the Centro Vitivinicola Nacional was to facilitate the registration of brands by producers.

39 José Trianes wrote that «Para vender lo que venden aquí dos docenas de los llamados vitivinicultores se necesita en Francia un centenar de comerciantes con un centenar de millones de francos en efectivo que han de comprar el producto de algunos millares de cosecheros» (Trianes 1908, p. 26).

40 Galanti (1900, pp. 26-27), Simois and Lavenir (1903, p. 200), Galanti (1915, p. 34) and Boletín Centro Vitivinícola Nacional (dic. 1910, p. 1671). For the 1930s, see Trianes (1935), cited in Mateu and Stein (2008, p. 157).

41 As one historian has noted, producers catered for «an expanding mass of consumers who demanded nothing more than a minimally palatable, abundant, low-priced and often adulterated product»(Stein 2007, p. 105). 
TABLE 6

SELECTED BRAND NAMES AND WINE PRICES IN JUNE 1910

\begin{tabular}{|l|c|c|c|}
\hline & & \multicolumn{2}{|c|}{ Price - centavos per litre } \\
\hline Winery & Brand & Mendoza & Buenos Aires \\
\hline Domingo Tomba & Tomba & $0.27^{*}$ & $0.32^{*}$ \\
\hline Giol \& Gargantini & Toro & 0.27 & \\
\hline Sociedad Bodegas Arizú & Arizú & 0.275 & 0.32 \\
\hline Honorio Barraquero & Baco & $0.25^{*}$ & \\
\hline Sociedad Germania & Cigüena & 0.24 & \\
\hline B.y C. del Bono & & 0.23 & \\
\hline Herwig \& Cia. & Perdiz & 0.25 & \\
\hline Red wine in general 'sobre wagon' & & $23-27$ & \\
\hline Vinos de 'traslado' from winery & & $15.0-17.0$ & \\
\hline
\end{tabular}

*New barrels.

Source: Boletín Centro Vitivinícola Nacional (junio 1910, p. 1516).

wineries now colluded to keep grape prices artificially low, at a little more than a peso per 42 kilograms between 1914 and 1919, when in 1912 and 1913 they had been 4.5 and 3.5 pesos, respectively. This price hardly covered variable production costs in the vineyards and thereby reduced the incentives to increase the supply of grapes by new plantings ${ }^{42}$.

Instead of a trust along the lines of the CWA, the leading producers looked to the Provincial government to stabilize the sector using government funds ${ }^{43}$. A number of schemes were debated, but the Mendoza law of 1916 (ley 703) was the most controversial. It created a «cooperative» that allowed the leading wineries access to taxes to remove unwanted production from the market. Past attempts to create voluntary organizations to control supply had failed because insufficient producers were willing to participate, so a punitive tax was levied on the production of those who remained outside the scheme ${ }^{44}$. This «cooperative» was run by the large wineries, but its life

42 The area of vines officially increased during this period, but this appears to reflect the poor quality of official statistics rather than growers increasing the area.

43 The leading growers enjoyed close links with the Provincial Government, and the industry produced as much as a half of the province's tax revenue and still accounted directly for 60 per cent of Mendoza's gross industrial output in 1914. Richard Jorba (2008, p. 7) writes that viticulture allowed the province "an important degree of independence» with respect to the Federal Government, as does Coria López (2008, anexo viii). Local industries were also highly dependent on the sector. See especially Pérez Romagnoli (2006). 
proved short as the Supreme National Court determined it unconstitutional because a Provincial Government could not create a monopoly ${ }^{45}$.

\section{CONCLUSION}

This paper argues that because grape quality was both inferior and highly volatile in Europe, growers could not guarantee a market for their grapes and therefore made the wine themselves. In the New World, this was not the case, and these activities were often carried out by separate entities with winemakers taking advantage of new technologies which greatly increased the scale of operations. Differences in the organization of winemaking and selling in the New World can be attributable to wine quality and this in turn to consumer demand. Many consumers in California and Australia were not accustomed to drinking wine and producers therefore had to improve and guarantee quality, which was achieved by either a producer-driven commodity chain (CWA) or by a market-driven chain (Burgoyne). By contrast, in Argentina the consumers were accustomed to drinking wine, and producers competed on price rather than quality. The leading producers agreed on compulsory inspections of winemaking and merchants' properties to establish a minimum, albeit low, standard for quality.

Despite the considerable achievements between 1890 and 1914, the future prospects for the industry on the eve of the First World War were not good. In California, the CWA disappeared with Prohibition after several attempts to reorganize itself. After Prohibition, when the industry effectively had to start again from scratch, integration occurred once more, but this time it was the out-of-state firms that moved into California and bought up the wineries (Lapsley 1996; Pinney 2005). By contrast, in Australia the narrowness of the domestic market made export performance especially important. Exports peaked as early as 1902 (although a second peak in 1911 was only marginally lower). The growth in British demand for dessert rather than dry table wines in the interwar period was not anticipated by Burgoyne and led to the firm's demise, while large vertically integrated wine companies exported dessert wines through State organized depots (Faith 2003). By the 1960s, dessert wines accounted for half of all Australian and Californian production, and it has only been in recent decades that the relative importance of table wines has returned to late $19^{\text {th }}$ century levels. Dessert wines were easier to brand than dry table wines, and by the late $20^{\text {th }}$ century, large-scale vertically and

44 This was set at eight pesos per hectolitre of wine and six pesos per quintal of grapes when market prices during the previous year had been just six and three pesos, respectively (Mateu 2007, p. 16).

45 Attempts by growers before 1914 to create cooperatives, such as those found in the Midi, found little support with the Provincial government as they would have threatened the grape supplies of the large wine producers. 
horizontally integrated companies in Jerez or Porto diversified their products, just as Seppelt did in Australia, and the CWA in the United States before Prohibition.

By contrast, in Argentina the industry suffered severely from the 1914 to 1919 crisis. For decades, domestic consumption failed to rise much above 60 litres per person per year, and population growth slowed as immigration declined. Although many of Mendoza's governors were themselves wine producers, the dependence of the Provincial government on wine encouraged it to try to develop alternative sources of revenues, while national politicians threatened to reduce tariffs on imports when they thought that wine companies were colluding or when quality deteriorated because of fraud. In Mendoza and California, the political climate was relatively permissive to big business and trusts, and both regions, with less than 5 per cent of their nation's population, produced around 95 per cent of the domestic wine supply. Unlike California however, wine was a basic commodity in the Argentine diet, and the Buenos Aires government was unwilling to permit a trust or monopoly to manipulate prices, while regulators were much less concerned in the United States. Under Perón, the national policy to supply plentiful cheap wines for the expanding middle and lower classes in urban markets would further restrict profitability (Stein 2007, p. 102).

\section{BIBLIOGRAPHY}

Periodicals and journals.

Australian vigneron and fruit-growers journal, Sydney.

Boletín Centro Vitivinícola Nacional, Buenos Aires.

Diario Los Andes, Mendoza.

Diario El Comercio, Mendoza.

La Prensa, Mendoza.

Pacific Rural Press, San Francisco.

Pacific Wine \& Spirits Review, San Francisco.

\section{REFERENCES}

Alazraqui, J. (1911): «La viticulture en Argentine», in International Congress of Viticulture. Montpellier: Coulet.

Amerine, M. A., and Singleton, V. (1976): Wine: An Introduction. Berkeley: University of California Press.

Arata, P., Garola, L., Lavenir, J., and Simois, D. (1904): Investigación vinícola complementaria de 1904. Trabajos presentados al Ministro de Agricultura por la comisión compuesta por....

Augé-LaRibÉ, M. (1907): Le problème agraire du socialisme: la viticulture industrielle du Midi de la France. Paris: Giard \& Brière. 
Barrio de Villanueva, P. (2003): «Hacia la consolidación del Mercado Nacional de Vinos. Modernización y desarrollo del sector vitivinícola de Mendoza (Argentina), 19001914». Espacios - Historia 26, pp. 33-60.

BarRio de Villanueva, P. (2006): «Las asociaciones de empresarios vitivinícolas mendocinos en tiempos de crisis y de expansión económica (1900-1912)», in R. A. Richard Jorba, E. Pérez, P. Barrio, and I. Sanjurjo (eds), La región vitivinícola argentina. Transformaciones del territorio, la economía y la sociedad, 1870-1914. Buenos Aires: Universidad Nacional de Quilmas, pp. 181-232.

BarRio de Villanueva, P. (2008a): «El empresariado vitivinícola de la provincia de Mendoza (Argentina) a principios del siglo XX». Historia Agraria 45, pp. 81-111.

Barrio de Villanueva, P. (2008b): «Una crisis de la vitivinicultura mendocina a principios del siglo XX (1901-1903)», in A. M. Mateu, and S. Stein (eds), El vino y sus revoluciones. Mendoza: EDIUNC, pp. 325-339.

Barrio de Villanueva, P. (2009): «Caracterización del boom vitivinícola en Mendoza (Argentina), 1904-1912». Mundo Agrario 18, pp. 1-19.

Bell, G. (1993): "The South Australian Wine Industry 1858-1876». Journal of Wine Research 4 (3), pp. 147-163.

Birebent, P. (2007): Hommes, vignes et vins de l'Algérie Française (1830-1962). Nice: Gandini.

California. State Agricultural Society (1915): Report of the California State Agricultural Society for 1914. Sacramento: California State Agricultural Society.

Campbell, C. (2004): Phylloxera. How Wine Was Saved for the World. London: HarperCollins.

CARMONA, J., and Simpson, J. (2010): Explaining Contract Choice: Vertical Co-ordination, Sharecropping, and Wine, France 1850-1950, Working Papers in Economic, number 15, Universidad Carlos III de Madrid.

Castella, DE H. (1886): John Bull's Vineyard. Melbourne: Sands \& McDougall.

Centro Vitivinícola Nacional (1910): La viti-vinicultura en 1910. Buenos Aires: Coll.

CoAse, R. (1937): «The Nature of the Firm». Economica 4 (16), pp. 386-405.

CocKs, C., and FÉRET, É. (1898): Bordeaux et ses vins classés par ordre de mérite, 7 th edn. Bordeaux: Féret.

Coria LóPez, L. (2008): «Producto bruto geográfico de Mendoza para 1914. Determinación y resultados», in XLIII Asociación Argentina de Economía Política. Córdoba.

FaIth, N. (2003): Australia's Liquid Gold. Chatham: Mitchell Beazley.

France Annuaire Statistique Année 1938 (1939): Direction Générale. Paris: Imprimerie Nationale.

GaLANTI, A. (1900): La industria vitivinícola argentina. Buenos Aires: Ostwald.

Galanti, A. (1915): Estudio crítico sobre la cuestión vitivínicola; estudios y pronósticos de otros tiempos. Buenos Aires: Perrotti.

Galassi, F. (1992): «Tuscans and Their Farms: The Economics of Share Tenancy in Fifteenth Century Florence». Rivista di storia economica 9, pp. 77-94.

Galet, P. (2004): Cépages et vignobles de France. Tome III Les vignobles de France, vol. 2. Paris: Tec \& Doc.

GerefFi, G. (1994): «The Organisation of Buyer-driven Global Commodity Chains», in G. Gereffi, and M. Korzeniewicz (eds), Commodity Chains and Global Capitalism. Westport, CT: Greenwood Press.

GERVAIS, C. (1903): Indicateur des vignobles méridionaux, comprenant l'Hérault, l'Aude, le Gard, les Pyrénées-Orientales, les Bouches-du-Rhône, le Vaucluse, la Drôme, le Var, l'Algérie (départements d'Alger, d'Oran, de Constantine), la Tunisie, 2nd edn. Montpellier: Firmin, Montane and Sicardi. 
Heintz, W. F. (1990): Wine country: A History of Napa Valley: The Early Years, 1838-1920. Santa Barbara: Capra.

HenRIKSEN, I. (1999): «Avoiding Lock-in: Co-operative Creameries in Denmark, 1882-1903». European Review of Economic History 9 (3), pp. 365-397.

Hoffman, P. (1984): «The Economic Theory of Sharecropping in Early Modern France». Journal of Economic History 42, pp. 155-162.

Holmström, B., and Roberts, J. (1998): «The Boundaries of the Firm Revisited». Journal of Economic Perspectives 12 (4), pp. 73-94.

International Institute de Agriculture (1915): Yearbook for 1913 and 1914, Roma.

IsNARD, H. (1954): La vigne en Algérie; étude géographique, vol. 2. Ophrys: Gap.

KAERger, K. (1901): La agricultura y la colonización en Hispanoamérica. Buenos Aires.

Klein, B.; Crawford, R., and Alchian, A. (1998): "Vertical Integration, Appropriable Rents, and the Competitive Contracting Process». Journal of Law and Economics 21, pp. 297-326.

Lains, P., and SousA, P. (1998): «Estatística e produção agrícola em Portugal, 1848-1914». Análise Social 33, pp. 935-968.

Lafontaine, F., and Slade, M. (2007): «Vertical Integration and Firm Boundaries: The Evidence». Journal of Economic Literature XLV (3), pp. 629-685.

Lamoreaux, N. R. (1985): The Great Merger Movement in American Business, 1895-1904. Cambridge; New York: Cambridge University Press.

Lapsley, J. T. (1996): Bottled Poetry. Napa Winemaking from Prohibition to the Modern Era. Berkeley, Los Angeles and London.

Law, M. T., and Libecap, G. D. (2006): «The Determinants of Progressive Era Reform: The Pure Food and Drugs Act of 1906», in E. L. Glaeser, and C. Goldin (eds), Corruption and Reform: Lessons from America's Economic History. Chicago: University of Chicago Press, pp. 319-342.

Loubère, L. A. (1978): The Red and the White. The History of Wine in France and Italy in the Nineteenth Century. Albany: State University of New York Press.

Mateu, A. M. (2007): «Los caminos de construcción del cooperativismo vitivinícola en Mendoza, Argentina (1900-1920)», in Documentos de Trabajo, no. 176. Buenos Aires: Universidad de Belgrano.

Mateu, A. M., and Stein, S. (2008): El vino y sus revoluciones. Mendoza.

Morgan, P. T. (1902): «The Outlook for the Wine Interest». Pacific Rural Press (August 9).

Morilla Critz, J. (ed.) (1995): La irrupción de California en el mercado de productos vitícolas y sus efectos en los países mediterráneos (1865-1925), in California y el Mediterráneo. Madrid: MAPA.

Nourrisson, D. (1990): Le buveur du XIXè siècle. Paris: Albin Michel.

Osmond, R., and ANDERson, K. (1998): Trends and cycles in the Australian wine industry, 1850-2000. Adelaide: Centre for International Economic Studies, University of Adelaide.

Pacottet, P. (1911): Vinificación en la provincia de Mendoza. Paris: Bailliere.

Pan-Montojo, J. L. (1994): La Bodega del Mundo. Historia de la vitivinicultura en España, 1800-1936. Madrid: Alianza.

Paul, H. W. (1996): Science, Vine, and Wine in Modern France. Cambridge: Cambridge University Press.

Peninou, E. P., and Unzelman, G. (2000): The California Wine Association and Its Member Wineries, 1894-1920. Santa Rosa, CA: Nomis.

Pérez Romagnoli, E. (2006): «Las industrias inducidas y derivadas de la vitivinicultura en Mendoza y San Juan (1885-1914)», in A. Richard Jorba (ed.), La región vitivinícola argentina. Buenos Aires: Quilmes, pp. 133-180. 
Pinney, T. (1989): A History of Wine in America: From the Beginnings to Prohibition. Berkeley: University of California Press.

Pinney, T. (2005): A History of Wine in America: From Prohibition to the Present. Berkeley: University of California Press.

Pouget, R. (1990): Histoire de la lutte contre le Phylloxéra de la vigne en France. Paris: INRA.

Richard Jorba, R. (1998): Poder, economía y espacio en Mendoza, 1850-1900: del comercio ganadero a la agroindustria vitivinícola. Mendoza: Universidad Nacional de Cuyo.

RichaRD JoRBA, R. (2008): "Los empresarios y la construcción de la vitivinicultura capitalista en la provincia de Mendoza (Argentina), 1850-2006». Scripta Nova xii (271).

Roberts, J. (2004): The Modern Firm. Oxford University Press.

Rocchi, F. (2006): Chimneys in the Desert: Industrialization in Argentina During the Export Boom Years, 1870-1930. Stanford: Stanford University Press.

SEFF, J., and Cooney, J. F. (1984): «The Legal and Political History of California Wine», in D. Muscatine; M. A. Amerine, and B. Thompson (eds), The Book of California Wine. Berkeley, Los Angeles, London: University of California Press/Sotheby.

Sempé, H. (1898): Régime économique du vin. Production, consommation, échange. Bordeaux: Féret.

Shear, S., and, Pearce, G. (1934): «Supply and price trends in the California wine-grape industry». Giannini Foundation Mimeo, 34.

Simois, D., and Lavenir, J. (1903): «El cultivo de la viña y la elaboración del vino en la provincia de Mendoza», in P. Arata (ed.), Investigación Vinícola. Buenos Aires.

Simon, A. L. (1919): Wine and Spirits: The Connoisseur's Textbook. London: Duckworth.

Simpson, J. (2004): «Selling to Reluctant Drinkers: the British Wine Market, 1860-1914». Economic History Review LVII (I), pp. 80-108.

Simpson, J. (2005): «Cooperation and Conflicts: Institutional Innovation in France's Wine Markets, 1870-1911». Business History Review 79 (Autumn), pp. 527-558.

Simpson, J. (2008). «California and the Creation of a Modern Wine Industry: 1860-1919». In Universidad Carlos III de Madrid, Working Papers in Economic History, 08-14.

Simpson, J. (2011): Creating Wine: The Emergence of a World Industry, 1840-1914. Princeton: Princeton University Press.

South Australia. (1901): Report of the Wine and Produce Depôt.

SteIN, S. (2007): "Grape Wars. Quality in the History of Argentine Wine», in G. Campbell, and N. Guibert (eds), Wine, Society and Globalization. Multidisciplinary Perspectives on the Wine Industry. Basingstoke: Palgrave Macmillan.

Trianes, R. (1935): Tres estudios sobre la cuestión vinícola. Eco.

Trianes, J. (1908): Por la viticultura Argentina y por el consumidor Argentino. Buenos Aires.

Victoria (1900): Royal Commission on Refrigerating Stores and Central Wine Depôt. Report on Central Wine Depôt. Melbourne: Government Printer.

Whitington, E. (1903, reprinted 1997): The South Australian Vintage 1903. Adelaide: Friends of the State Library of South Australia.

Young, A. (1794): Travels during the Years 1787, 1788 and 1789, Undertaken ... the Kingdom of France, vol. 2. Bury St. Edmunds: Richardson. 